doi: $10.15503 /$ jecs20191.68.75

\title{
THE SIGNIFICANCE OF EDUCATIONAL ACTIVE- NESS AMONG THE ELDERLY IN A SOCIAL AND PSYCHOLOGICAL CONTEXT
}

\author{
ALEKSANDRA MARCINKIEWICZ-WILK \\ Faculty of Pedagogy, University of Wroclaw, \\ ul. J. W. Dawida 1, Wroclaw, Poland \\ E-mail address: aleksandra.marcinkiewic-wilk@uwr.edu.pl \\ ORCID: 0000-0001-8016-6884
}

\begin{abstract}
Aim: The aim of this article is to show the significance of educational activeness among the elderly in the context of its adaptation to the ageing process itself (the psychological aspect), as well as to a rapidly changing society defined by technological progress (the social aspect).

Method: The article has been formulated with the aid of critical literature on the subject.

Conclusion: Educational activeness is crucial in late adulthood. On the one hand it is an important element in allowing the elderly to adapt to a new stage of life, and on the other hand to keep up with a rapidly changing society, defined in the literature as the information society.

Key words: old age, learning, educational activeness, education, information society, adaptation to old age.
\end{abstract}

$\mathrm{T}$

he contemporary reality is characterised by rapid changes caused by the development of information technology. The dynamic of these changes means that knowledge and skills acquired soon become redundant, and it is essential that they are constantly updated. Keeping up with these changes is a challenge for us. The 21st century is unstable and unpredictable, and established behaviour patterns are often irrelevant to the present world. This forces people to make non-standard decisions, with no certainty that they will be effective.

This situation is extremely relevant to the society because, along with the changes created by the information society, developed countries are facing an increasingly ageing population. The threat of an increasing number of elderly people becoming marginalised in the information society poses a huge problem, and its solution is one of the priorities for European nations.

The changes which occur during the course of people's lives require them to have the ability to adapt. This is particularly important in old age, a stage of life which brings many changes, both positive (e.g. wisdom, experience, and 
reflectiveness) and negative (e.g. deteriorating health and the loss of nearest and dearest). Old age is perceived as a process during which there is an accumulation of uncertainty regarding one's own self-image, as a consequence of having ceased to fulfill certain social functions. An attempt to define various mechanisms for adaptation to old age has been made, based on observation of the social behaviour of the elderly. The most well-known are the "disengagement theory" and its opposite the "active theory."

The "disengagement theory" was formulated during the 1960s on the basis of work carried out by Elaine Cumming and Williama E. Henry. According to this approach, disengagement from social life is a natural and functional need in the development of the elderly. Passivity and disengagement from social activity are just as relevant as the active engagement of young people in social life. Ceasing social activity should be conducive to reflecting on memories, reinterpretation of past memories and the discovery of new meanings. According to this theory, disengagement forms an inseparable part of the life of the elderly, but does not fulfill its function until later old age, and is a process which one can approach voluntarily (J. Rembowski, 1984, pp. 34-35). This is what is known as the "rocking chair" style of life.

This theory has been challenged on both theoretical and empirical grounds. Despite its limitations, it turned out to be very important in the development of gerontology because it was the first general concept which attempted to explain ageing by pointing out the attributes regulating its process. This gave rise to a polemical discussion on the subject and the creation of an opposing concept of ageing, which in turn led to the theory of active old age (Halicki, 2010, p. 14).

This opposing theory became known as the "active theory" developed B. L. Neugarten, R. J. Havighurst and S. S. Tobin, which advocates an active part in social life after retirement. This concept recognises that the ageing process allows people to maintain their engagement in life. Successful ageing depends on remaining active, finding a replacement for professional activity or lost love and forming new relationships. According to the theory, activity is a conditional factor in successful ageing and life satisfaction (J. Rembowski, 1984, pp. 34-35). Supporters of this approach consider that the elderly do not wish to remain locked in their own internal life based on a psychological distance from the rest of the world (Halicki, 2010, p. 14).

In its most general sense, activeness may be understood as an active life style and active participation in various spheres of life, including physical, mental and intellectual activity (Halicka \& Halicki, 2003, p. 190).

Activeness and staying in contact with other people are important elements of a satisfactory life in old age. They are perceived as an essential condition for integrating the individual with the outside world, leading to a fulfilled later life. For this reason, the theory of activeness in later life enjoys enormous popularity among gerontologists.

Activeness is an essential condition for satisfying the biological, social and cultural needs of the elderly. It helps them become members of a group and 
participate in social activity (Szatur-Jaworska, Błędowski \& Dzięgielewska, 2006). Jerzy Semków (2000, p. 28) states that the more considered and diverse activities for the elderly are, the wider their life space becomes, the more the number and quality of their inter-personal relationships increases, and the wider their achievements become in the mental, physical and intellectual spheres. Thus, it can be argued that activeness forms the basis of one's development and is conducive to social interaction. The origin of activeness for the elderly is their needs, emphasising that they can be satisfied by activeness itself.

The factors which affect the form and type of activeness for the elderly can be enumerated as follows (Szatur-Jaworska, Błędowski \& Dzięgielewska, 2006, pp. 161-162):

- Education - the level of activeness increases with the level of education;

- Engagement in family life - the level of activeness is dependent on personality, origin and contact with close family;

- State of health - the healthier one is, the more likely they are to take part actively;

- Material status - financial difficulties can effectively limit some types of activity;

- Location - there are far more opportunities for the elderly in cities than in small towns and villages;

- Influence of cultural institutions - activeness among the elderly is greater where cultural centres operate;

- Gender - as there are more women in retirement they play a greater role.

Activeness performed in late adulthood can have many functions (Szatur-Jaworska, Błędowski \& Dzięgielewska, 2006, p. 164), including:

- Adaptive, which depends on the elderly adapting to a new social and family situation

- Integrational, helping the elderly to fulfill themselves in a group, create new inter-personal relationships and increase the number of informal contacts

- Compensational, which can balance shortcomings in other fields (e.g. in connection with ceasing to function in a particular social role);

- Educational, leading to personal development and predisposition;

- Recreational and entertaining, helping to reduce stress and occupy free time;

- Psycho-physical, which raises self-esteem and satisfaction, thus improving the quality of life.

Maintaining an active life style is essential to experiencing a positive old age. In the context of the challenges which come with both the information society and an ageing population, educational activeness among the elderly appears to be particularly relevant, especially that the changes in the ability to learn with the advancement of age are not as marked as is generally thought. The differences between the younger and older generations concern above all perception, motivation and physical fitness, and not the ability to learn. 
All people (including the elderly) need to acquire new competences and develop those which they already have. One should use the potential of their own strengths, skills and abilities. Life opportunities, physical health and skills are treasures which one cannot afford to lose. People should strive to survive and reflect on themselves, theirlives and the world around them. Consciousness awakened by learning confirms and humanises a person. Inspired by the opinion of Olga Czerniawska (2010, p. 52) on the subject of adult education, educational activeness should be seen against the background of switching from teaching others to learning oneself. The object of educational activeness is to create an education programme, analyse one's own life, learn from the life experience of oneself and others, and to obtain wisdom from one's peers as well as the younger generation.

Educational activeness should be understood as an intentional and active participation in various forms of education - formal, extra-formal and informal.

Andragogy recognises three factors in connection with the motivation of adults to learn-cognitive ability, self-confidence, and control over the learning process. The first is a generalisation related to cognitive ability as perceived by the adults themselves as to whether they are capable of coping with the material (e.g. some consider themselves incapable of learning mathematics or a foreign language). Self-knowledge on this subject can either motivate or demotivate an individual from participating in educational activity. The second factor refers to an individual's self-confidence as to whether they are capable of learning anything at all. If an individual is confident in their own abilities, they will consequently greater effort ino achieving their education goals. If, however, an individual is not sure whether they "can cope" with a particular challenge, they have a low level of motivation. In turn, if an individual is convinced of the high level of their own abilities, they are confident that they have some control over the education process. A sense of internal control comes when an individual considers that the course of events in the education process is the result of their own actions. On the other hand, when the results of a particular event are perceived by the individual to be caused by external factors over which they have no influence, it is referred to as external control. Individuals who feel some kind of internal control are more determined to overcome difficulties during the education process (Malewski, 1998, p. 57).

As shown above, the question of whether an adult participates in learning, and in what form, depends on motivation. There are three categories of participant in adult education (Malewski, 1998, p. 53):

- Oriented by education goals - characterised by an instrumental approach to education. Their motivation is the acquisition of knowledge and skills to assure them social advancement;

- Oriented by participation in education - for whom educational activeness is an opportunity to meet others and combat loneliness;

- Oriented cognitively and developmentally - for whom learning is a means of widening their knowledge and developing themselves generally. 
A link can be seen between the age of adults and their motivation when it comes to learning. Young adults generally take a pragmatic approach to education. They treat it instrumentally, as a means of achieving their aims regarding work and social advancement. Adults whose life has stabilised and who are not subject to social pressure are more likely to be motivated for cognitive reasons. (Malewski, 1998, p. 53). This latter group also includes the elderly, as they no longer need to educate themselves to find better work or improve their social position.

Educational activeness for seniors should be seen from two different perspectives - as a factor in the senior's development and as a preparation for the life in the information society. Olga Czerniawska (2011, p. 53) expertly describes the present need for lifelong learning: "Openness to change, flexibility and a search for knowledge are the basis for functioning in the post-industrial society, and continuous education is able to provide these. It teaches how to cope with full-time and part-time work, with employment and unemployment. It teaches flexibility and coping with swift and sudden change, and shows how to have an open approach to such changes." Educational activeness for the elderly helps them to adapt to old age and find themselves in a new social reality, and at the same time adds to their personal development.

The question of education in its wider sense, including that for the elderly, has been tackled by some gerontologists. The attitudes of the elderly towards education and the factors forming such attitudes was the subject of some research carried out by Magdalena Pakuła (2010). Her research results show that among the elderly, education enjoys high status, and they share positive assessment thereof.

On the other hand, Barbara Z. Małecka (2000, pp. 131-136) carried out research into the educational space of seniors, and the factors deciding the choice of behaviour in such space. The author treats education in a wide sense because she assumes the premise that "every sphere of an individual's activity contains an element of educational activeness and they are all linked to willingness to change, openness, and sensitivity to a reinterpretation of the past." Her scientific research showed that the dominant educational activity among the elderly is watching television. What is more, only some of the people researched were able to define aims, reasons, content and method in creating their own educational space.

Another matter frequently addressed by researchers into education for the elderly is that of learning through biography. Among those who have carried out such research are Duccio Demetrio (2000), Elżbieta Dubas (1993), Olga Czerniawska (2011), and Anna Frąckowiak (2009). The results of their research show above all the diversity of educational paths presented by seniors. They also highlight the educational potential in the very process of constructing a biography.

Nevertheless, in the literature on the subject education of the elderly is seen above all in the context of intellectual stimulation within the framework of the University of the Third Age (extra-formal education). As members of 
the U3A, seniors participate in lectures, sections, seminars, interest circles and a wide range of courses. Lectures are the basic form of activity in the U3As, mostly devoted to illnesses of old age and the preservation of health. The U3As also attempt to break down the mistrust which the elderly feel towards new technology. The term e-inclusion denotes activities aimed at combatting digital illiteracy and including Europe's oldest citizens in the digital society. Among others, U3As offer courses in computer use, net browsing and using e-mail. These courses are aimed at familiarising the participants with ICT technologies, and concentrate on the benefit these technologies can bring to seniors in their daily lives (Szarota, 2008).

Educational activeness for seniors should also be seen from the life-long learning aspect with reference to formal, extra-formal and informal education. As has already been shown, education occupies a central position in the idea of life-long learning, which is considered to be a pillar of the information society. The significance of education in the information society is evidenced by the fact that it is one of its fundamental dimensions or attributes (Lubański, 2004, p. 15). What is more, the challenges posed by the information society require specific skills in order to participate in social life. These skills may be obtained through participation in formal, extra-formal and informal education. Additionally, the dynamic of rapid change in the information society means that skills and abilities quickly become out-dated, so in order to keep up with the these changes the learning process should be extensive and continuous. However, education and learning are not only the road to creating a new society, but also an essential and inseparable element of one's life (Kurantowicz, Nizińska, 2012, p. 19): "Education is the 'to be or not to be' of contemporary man, existing in a world of constantly increasing competition and destabilisation of social values, we live in a world of unprecedented economic, technological and social change. (...) the fact that life-long learning is the subject of numerous government discussions is evidence that its potentially revolutionary implications are recognized."

Learning in a fast-changing society, especially for seniors, can also take the form of transgressional learning. According to this concept, an individual is able to beyond their hitherto limits of achievement: "Transgression is ingenious and expansive activities which go beyond normal boundaries, actions thanks to which an individual or a group create new structures or destroy already established go structures, forming new values both positive and negative. Such actions are the source of development and regression" (Kozielecki, 1987, p. 132). Thus, not only can people continue learning throughout their lives (life-long learning), but they can also learn completely new information and skills. This is especially relevant in the face of the dynamic changes which characterise the information society.

The transgressional aspect of learning in the context of the information society is apparent in the case of the elderly. This results from the fact that seniors were brought up in a different social reality. When they were young they did not have to deal with new technologies, and the world around them 
was fairly stable and predictable. The new reality in which they find themselves in old age cannot be compared to the one they knew in the past. Older people often experience transgressional learning because what they are currently learning things they have never experienced before. One can also observe a certain analogy to the theory of transformative learning formulated by Jack Mezirow, which states that the highest level of learning depends on the rejection of known patterns which, according to the authors, limit the cognitive perspective and the acquisition of new patterns (Malewski, 1998, pp. 112-114).

Participation in life-long learning, and the more so in transgressional learning, is nothing more than a certain type of activeness. There are three basic factors which are conducive to transgressional learning among the elderly activeness, positive assessment of one's own ability, and engagement in social life. The most important factor facilitating transgressional learning among the elderly is activeness in its broadest sense - an active life-style and participation in various spheres of life. This applies to physical as well as mental and intellectual activity (Halicka \& Halicki, 2003, p. 190), leading to the other two factors. One of them is a positive assessment of one's own ability, which manifests itself as satisfaction with one's life style and decisions. The remaining factor is engagement in social life, which means keeping in contact with old acquaintances and making new ones and taking a voluntary part in the local community. On this basis it can be stated that seniors who lead an active life, have a positive assessment of their own ability and are socially engaged will experience transgressional learning more frequently and more easily (Marcinkiewicz \& Cutter, 2014, pp. 149-158). One can also assume that these people will cope with social change more easily, enabling them to fully participate in social life.

The considerations outlined above indicate that educational activeness is taking on a new form because it applies to both the ageing process itself and adaptation to a dynamically changing society. People are placed in a certain socio-cultural context which is not without significance for their education. There is no doubt that educational activeness plays an important role in adapting to a changing society. Older people who continue learning take a positive view of the changes brought about by the information society. They are aware of the challenges which the new reality brings, and through education try to level the negative results of social development, at the same time taking full advantage of its positive aspects. Educational activeness for the elderly can be seen not only in adaptation but above all in the humanist aspect as the personal development of an individual. 


\section{BIBLIOGRAPHY}

[1] Czerniawska, O. (2011). Nowe drogi w andragogice i gerontologii [New ways in andragogy and gerontology]. Łódź: Wydawnictwo Akademii Humanistyczno-Ekonomicznej.

[2] Demetrio, D. (2000). Autobiografia: terapeutyczny wymiar pisania o sobie [Autobiography: the therapeutic dimension of writing about oneself]. Kraków: Impuls.

[3] Dubas E. (1993). Linie edukacyjne rozwoju człowieka [Educational lines of human development]. In: A. Trzustkowski (ed.), Edukacja dorostych w sytuacji przemian na tle porównawczym: Międzynarodowa Konferencja Łódź, 27-29 września 1993 [Adult education in a situation of changes against a background of comparative changes: International Conference Łódź, 27-29 September 1993]. Łódź: Uniwersyet Łódzki.

[4] Frąckiewicz E.(2009). The influence of the Internet on the activity of senior citizens from the point of view of the i2010 strategy for the building of the information society. Warszawa: Centrum Europejskie Natolin.

[5] Halicka, M., Halicki, J. (2003). Integracja społeczna i aktywność ludzi starszych [Social integration and the activity of the eldely]. In: B. Synak (ed.), Polska Starość [Polish old age] (pp. 189-218). Gdańsk: Wydaw. Uniwersytetu Gdańskiego.

[6] Halicki, J. (2010). Obrazy starości: rysowane przeżyciami seniorów [Pictures of Old Age: seniors' experiences in drawing]. Białystok: Wydawnictwo Uniwersytetu w Białymstoku.

[7] Kozielecki, J. (1987). Koncepcja transgresyjna człowieka [The transgressive concept of man]. Warsaw: PWN.

[8] Kurantowicz, E., Nizińska, A. (2012). Trajektorie uczenia się w instytucjach ksztatcenia ustawicznego [Trajectories of learning in life-long learning institutions]. Wrocław: Wydawnictwo Naukowe Dolnośląskiej Szkoły Wyższej.

[9] Lubański, M. (2004). Społeczeństwo informacyjne a cywilizacja informatyczna [Information society and IT civilization]. In: A. Szewczuk (ed.), Dylematy cywilizacji informatycznej [Dilemmas of the information civilization] (pp. 11-38). Warsaw: Polskie Wydaw. Ekonomiczne.

[10] Malewski, M. (1998). Teorie andragogiczne. Metodologia teoretyczności dyscypliny naukowej [Andragogical theories. Methodology of theoretical science discipline]. Wrocław: Wydaw. Uniwersytetu Wrocławskiego.

[11] Małecka, B. Z. (2000). Przestrzeń edukacyjna w życiu ludzi starszych (refleksja teoretyczne i doświadczenia empiryczne) [Educational space in the lives of older people (theoretical reflection and empirical experience)]. In: M. Dzięgielewska (ed.), Przestrzeń życiowa i społeczna ludzi starszych [The living and social space of older people] (pp. 133-136). Łódź: Akademickie Towarzystwo Andragogiczne.

[12] Marcinkiewicz, A., Cutter, Z. (2014). Transgresyjne uczenie się seniorów w społeczeństwie informacyjnym [Transgressive learning of seniors in the information socjety]. In: I. Paszenda, R. Włodarczyk (eds.), Transgresje w edukacji [Transgresions in education] (pp. 149-158). Kraków: IMPULS.

[13] Pakuła, M. (2010). Postawy osób starszych wobec edukacji: studium teoretyczno-diagnostyczne [Attitudes of older people towards education: a theoretical and diagnostic study]. Lublin: Wydawnictwo Uniwersytetu Marii Curie-Skłodowskiej.

[14] Rembowski, J. (1984). Psychologiczne problemy starzenia się cztowieka [Psychological problems of aging]. Warsaw-Poznań: PWN.

[15] Semków, J. (2000). Wielość wymiarów przestrzeni życiowej ludzi w III wieku [The many dimensions of the living space of people in the third age]. In: M. Dzięgielewska (ed.), Przestrzen życiowa $i$ spoteczna ludzi starszych [Living and social space of older people] (pp.27-32). Łódź: Akademickie Towarzystwo Andragogiczne.

[16] Szarota, Z. (2008). Przestrzeń edukacyjna Uniwersytetu Trzeciego Wieku. e-mentor, 3 (25), 71-76.

[17] Szatur-Jaworska, B., Błędowski, P., Dzięgielewska, M. (2006). Podstawy gerontologii społecznej [Basics of social gerontology]. Warsaw: Oficyna Wydawnicza Aspra-Jr. 